\title{
POLA ARGUMENTASI DALAM METODE DAKWAH MUJADALAH NABI IBRAHIM
}

\author{
Tri Djoyo Budiono \\ STID AL-HADID SURABAYA \\ djoyobudi@gmail.com
}

\begin{abstract}
Abstrak: Mujadalah menjadi salah satu metode para nabi dalam menyebarkan Islam. Dalam mujadalah atau debat, argumentasi mempunyai peran penting untuk menentukan keunggulan suatu pendapat dibandingkan yang lain. Salah satu argumentasi mujadalah yang bisa dijadikan pelajaran adalah mujadalah Nabi Ibrahim yang terdapat dalam Al-Qur'an. Tujuan tulisan ini ingin mengetahui pola argumentasi dalam mujadalah Nabi Ibrahim. Metode penelitian yang digunakan adalah kualitatif dan studi pustaka. Hasil kajian tulisan ini menunjukkan bahwa pola argumentasi dalam mujadalah Nabi Ibrahim bila dilihat dengan teori argumentasi Stephen Toulmin adalah: 1) Pernyataan (claim) yang dibangun senantiasa berkaitan dengan aspek tauhid, bahwa tidak ada Tuhan selain Allah. Menolak Tuhan selain Allah yakni patung-patung; 2) Dalam semua mujadalahnya, Nabi Ibrahim menggunakan pola argumentasi kelima, bangunan argumentasinya kuat disertai dengan serangan pemikiran (rebuttal) yang sulit dibantah; 3) Ketika berhadapan dengan masyarakatnya yang awam, Nabi Ibrahim menggunakan pendekatan empiris, sedangkan ketika berhadapan dengan ayahnya dan Raja Namrud, Nabi Ibrahim menggunakan pendekatan rasional; 4) Nabi Ibrahim dalam menyampaikan rebuttal, tidak selalu ada elemen backing ataupun modal qualifier. 5) Ketika lawan debatnya tidak mampu menjawab argumen serangan Nabi Ibrahim, mereka menggunakan serangan ancaman psikis maupun fisik, Nabi Ibrahim membalasnya dengan bahasa yang baik dan memohon pertolongan Allah.

Kata kunci: Argumentasi, Mujadalah, Debat, Nabi Ibrahim.
\end{abstract}

\begin{abstract}
Mujadalah became one of the prophet's methods in propagating Islam. In mujadalah or debate, an argument possesses an essential role in determining the strength of an opinion compared to others. One of the arguments in mujadalah which can be a lesson is the prophet Ibrahim's mujadalah stated in Al Qur'an. This discourse aims to identify the argument model in his mujadalah. It is a qualitative and library research. It shows that the argument pattern in that mujadalah, if it is viewed under Stephen Toulmin's model of argument, shows : 1) claims asserted were consistently related to the aspect of Tawhid that there is no God but Allah and refuses idols as Gods, 2) in all of his mujadalah, the prophet Ibrahim applied the fifth model of argument, his argument construction was sound followed with undebatable rebuttal; 3) While confronting against his common people, he applied empirical approach. While confronting against his father and King Namrud, he applied rational one; 4) In asserting rebuttals, he did not always need backing or qualifier: 5) When his opponents could not answer his argument and threatened him physically or psychologically, he replied in good words and asked Allah's Help.

Key words : Argument, Mujadalah, Debate, The prophet Ibrahim
\end{abstract}




\section{Pendahuluan}

Debat merupakan salah satu metode dakwah dalam menyebarkan ajaran Islam. Dalam bahasa Arab, metode diskusi dan debat ini sering dibahasakan dengan mujadalah. Mujadalah menurut Hasbi AshShiddieqy secara bahasa berasal dari kata jadal yang artinya bertukar pikiran (berdialog), termasuk saling menunjukkan keunggulan argumentasi untuk membuktikan kebenaran. ${ }^{1}$

Allah memerintahkan untuk mengajak manusia salah satunya dengan menggunakan mujadalah atau metode debat seperti yang tercantum dalam QS. AnNahl:125, "Serulah (manusia) kepada jalan Tuhanmu dengan hikmah dan pengajaran yang baik, dan berdebatlah dengan mereka dengan cara yang baik. Sesungguhnya Tuhanmu, Dialah yang lebih mengetahui tentang siapa yang tersesat dari jalan-Nya dan Dialah yang lebih mengetahui siapa yang mendapat petunjuk." 2

Dalam kenyataannya, mujadalah atau debat merupakan salah satu metode yang digunakan oleh para utusan Allah. Misalnya Nabi Musa dengan Firaun yang berdebat tentang ketauhidan dalam QS. Thaahaa (20):47-59. Nabi Muhammad juga menggunakan metode berdebat dalam menyampaikan dakwahnya. Salah satunya adalah berdebat dengan orang-orang Ahli Kitab seperti yang tercantum dalam QS. AlAnkabut (29):46. "Dan janganlah kamu berdebat dengan Ahli Kitab, melainkan dengan cara yang paling baik, kecuali

\footnotetext{
1 Hasbi Ash-Shiddieqy, Ilmu-ilmu Al-Qur'an: Mediamedia Pokok dalam Menafsirkan Al-Qur'an (Jakarta: Bulan Bintang, 1992), 7.

2 Departemen Agama RI, Al-Qur'an dan Terjemahannya (Surabaya: Penerbit Mekar, 2004), 383.
}

dengan orang-orang zalim di antara mereka, dan katakanlah: "Kami telah beriman kepada (kitab-kitab) yang diturunkan kepada kami dan yang diturunkan kepadamu; Tuhan kami dan Tuhanmu adalah satu; dan kami hanya kepada-Nya berserah diri."

Menurut Abd Karim Zaydan, mujadalah merupakan metode terbaik dalam komunikasi dakwah, karena di dalamnya terkandung keluasan ilmu Islam dan sebagai pembuktian untuk menguji kebenaran ajaran Islam. ${ }^{4}$ Metode mujadalah atau debat ini mempunyai kegunaan antara lain: 1) sebagai alat atau cara mencari kebenaran; 2 ) sebagai cara menguji kebenaran; 3) sebagai cara untuk mempertahankan kebenaran; 4) sebagai cara untuk mengajak kepada kebaikan dan mencegah kemungkaran. ${ }^{5}$

Metode debat adalah metode yang sering digunakan oleh para nabi ketika berhadapan dengan orang-orang yang menentang ajaran tauhid. Oleh karena itu, nabi-nabi Allah tidak jarang melakukan dakwah dengan metode debat untuk menunjukkan argumentasi dan bukti-bukti, siapa yang paling dapat dipertanggung jawabkan argumentasinya. Dengan metode debat, dapat diketahui bahwa ajaran tauhid adalah ajaran yang benar, ilmiah, bukti-buktinya sangat kuat. Sehingga bagi orang yang berakal sehat tentunya akan tergerak hatinya untuk mengikuti ajaran tauhid.

Dalam kaitannya dengan dakwah, Allah senantiasa memberikan tekanan agar

${ }^{3}$ Ibid., 566.

${ }^{4}$ Abd Karim Zaydan, Usul al-Da'wah (Baghdad: Dar Umar al-Khattab, 1982), 743.

${ }^{5}$ Nanih Machendrawati dan Aep Kusnawan, Teknik Debat dalam Islam, dari Konsepsi sampai Aplikasi (Bandung: Pustaka Setia, 2003), 30-31. 
bermujadalah atau berdebat dengan cara yang baik. Quraish Shihab menjelaskan bahwa makna jidal atau debat terdiri dari tiga macam. Pertama, jidal atau debat buruk yaitu debat yang disampaikan dengan katakata kasar, sehingga membuat marah lawan debat, serta menggunakan dalil-dalil atau argumentasi yang tidak benar. Kedua, jidal atau debat baik yakni debat yang disampaikan dengan kata-kata yang sopan, serta menggunakan dalil-dalil atau argumen yang bisa dipertanggung jawabkan. Ketiga, jidal atau debat terbaik yakni debat yang disampaikan dengan cara yang baik, didukung dengan argumentasi yang benar dan dapat membungkam pendapat lawan debat. Menurut Quraish Shihab jidal atau debat yang dianjurkan dalam QS. An-Nahl ayat 125 adalah debat yang terbaik. ${ }^{6}$ Dari pernyataan Quraish Shihab tersebut dapat dipahami bahwa kualitas argumen dalam mujadalah atau debat merupakan hal yang sangat penting.

Argumen dan argumentasi adalah sesuatu yang berbeda. Argumen adalah alasan yang dapat dipakai untuk memperkuat atau menolak suatu pendapat, pendirian, atau gagasan. ${ }^{7}$ Sedangkan argumentasi menurut Gorys Keraf merupakan suatu bentuk retorika yang dibangun agar bisa memengaruhi sikap dan pendapat orang lain, agar orang lain percaya dan bertindak sesuai dengan apa yang diharapkan oleh orang yang menyampaikan argumentasi. ${ }^{8}$ Sehingga argumen disini sebagai isi alasannya sedangkan argumentasi sebagai strategi dalam penyampaian argumen untuk

\footnotetext{
${ }^{6}$ M. Quraish Shihab, Tafsir Al-Mishbah, Pesan, Kesan dan Keserasian al-Qur'an, Cet. IV, Jilid. 6 (Jakarta: Lentera Hati, 2011), 776.

7 Kamus Besar Bahasa Indonesia Online, diakses tanggal 26 April 2020. https://kbbi.web.id/argumen.
}

mencapai tujuan komunikator dalam suatu debat.

Tarigan menyampaikan bahwa suatu argumentasi menentukan baik tidaknya suatu pendapat dalam memengaruhi orang lain, apakah akan didukung ataukah ditolak. ${ }^{9}$ Kualitas argumentasi yang baik, maka akan dapat menunjukkan keunggulan argumentasi dan melemahkan pendapat lawan, sehingga audiens yang melihat proses debat itu bisa tertarik untuk mengikuti pendapat atau argumentasi dari komunikator debat. Manfaat selanjutnya nilai-nilai Islam akan mudah diterima, disepakati dan diyakini oleh audiens sebagai komunikan dakwah. Sebaliknya argumentasi yang buruk akan melemahkan pendapat komunikator debat, sehingga akan mudah dipatahkan oleh lawan debat. Dampaknya audiens akan mengikuti pendapat lawan debat. Dampak selanjutnya kalau proses dakwah menggunakan metode debat, kemudian argumentasinya lemah, maka nilai-nilai Islam yang dibawa akan sulit meyakinkan audiens sebagai komunikan dakwah.

Permasalahannya, tidak jarang kita jumpai di berbagai kanal media, adanya fenomena mujadalah yang tidak baik atau debat kusir. Di mana mujadalah tersebut tidak dibangun dari argumentasi yang kuat. Tidak jarang debat kusir tersebut dilakukan dengan bahasa kasar, saling ngotot, atau emosi, menyudutkan secara personal, bahasa tubuh yang tidak sopan, menunjuk muka, bahkan sampai hampir terjadi pertengkaran. Berdasarkan penelitian dari Sabani, debat

8 Gorys Keraf, Argumentasi dan Narasi (Jakarta: Gramedia Pustaka Utama, 1991), 3.

9 Henry Guntur Tarigan, Berbicara Sebagai Suatu Keterampilan Berbahasa (Bandung:Aksara, 2008), 86. 
kusir terjadi di dunia virtual, dari sepuluh informan yang ditanyai kesemuanya melakukan debat kusir karena kepentingan pribadi, sekitar $20 \%$ dari informan merasakan kepuasan pribadi saat merasa yang paling benar dan sekitar $80 \%$ dari informan ternyata menyadari kegiatan tersebut hanyalah sia-sia karena tidak jelas akhir dari perdebatan itu, sebab tujuannya tidak untuk membuktikan kebenaran, tidak didukung argumentasi atau bukti-bukti yang kuat. ${ }^{10}$ Dengan adanya fenomena tersebut, perlu bagi komunikator dakwah untuk memahami tentang bagaimana menerapkan metode dakwah mujadalah atau debat dengan baik. Yakni metode debat yang mempunyai tujuan untuk menegakkan kebenaran dan dibangun oleh bukti-bukti yang kuat, serta mampu mematahkan argumentasi lawan dengan tajam.

Untuk membangun argumentasi debat yang baik, seorang komunikator dakwah bisa belajar dari Nabi Ibrahim. Sebab, karakteristik debat dan argumentasi yang dilakukan oleh Nabi Ibrahim memenuhi karakteristik debat yang baik seperti yang disampaikan oleh Shihab, yakni disampaikan dengan cara yang baik, dengan bahasa santun, tidak menghina secara pribadi, didukung dengan argumen yang disertai bukti-bukti yang kuat, serta mampu menunjukkan kelemahan pendapat lawan debat, sehingga lawan bingung dan tidak mampu membantahnya. Hal ini dapat diamati salah satunya dari proses debat Nabi Ibrahim dengan Raja Namrud dalam QS. AlBaqarah ayat 258, Allah berfirman yang artinya:

\footnotetext{
${ }^{10}$ Noveliyati Sabani, "Generasi Milenial dan Absurditas Debat Kusir Virtual," Jurnal INFORMASI: Kajian IImu Komunikasi vol. 48, no. 1 (2018): 95-108. doi: http://dx.doi.org/10.21831/informasi.v48i1. 18078
}

"Apakah kamu tidak memperhatikan orang yang mendebat Ibrahim tentang Tuhannya, karena Allah telah memberinya kerajaan (kekuasaan). Ketika Ibrahim berkata: "Tuhanku ialah Yang menghidupkan dan mematikan," dia berkata: "Akupun dapat menghidupkan dan mematikan." Ibrahim berkata: "Allah menerbitkan matahari dari timur, maka terbitkanlah ia dari barat." Maka bingunglah orang kafir itu. Allah tidak memberi petunjuk kepada orang-orang yang zalim."11

Allah juga memerintahkan umat Islam bahkan Nabi Muhammad untuk mengikuti Nabi Ibrahim, seperti yang tercantum dalam QS. An-Nahl (16):123, "Kemudian Kami wahyukan kepadamu (Muhammad): "Ikutilah agama Ibrahim seorang yang hanif" dan bukanlah dia termasuk orangorang yang mempersekutukan Tuhan". ${ }^{12}$ Salah satu yang perlu diteladani adalah pada aspek dakwahnya. Oleh karena itu, perintah menjalankan dakwah dengan metode dakwah yang terdapat dalam QS. An-Nahl ayat 125 itu sebenarnya satu wacana dengan perintah mengikuti Nabi Ibrahim di QS. An-Nahl 123. Sehingga yang dimaksud mengikuti dakwah mujadalah yang baik antara lain dapat dikaitkan dengan mujadalahnya Nabi Ibrahim. ${ }^{13}$

Tulisan ini, hendak mendalami tentang pola argumentasi mujadalah Nabi Ibrahim. Sebab, mujadalah yang dilakukan oleh Nabi Ibrahim tidak hanya satu proses mujadalah saja, ada beberapa proses mujadalah yakni mujadalah Nabi Ibrahim dengan ayahnya, dengan masyarakatnya, dan dengan Raja

\footnotetext{
11 Departemen Agama RI, Al-Qur'an dan Terjemahannya, 53-54.

12 lbid., 382

13 M. Quraish Shihab, Tafsir Al-Mishbah, 776.
} 
Namrud. Dengan memahami pola argumentasi dari beberapa proses mujadalah Nabi Ibrahim tersebut, akan didapatkan suatu pemahaman yang lebih menyeluruh tentang karakteristik atau kekhasan argumentasi mujadalah Nabi Ibrahim.

Penelitian terdahulu tentang mujadalah di antaranya adalah tulisan Priyanto berjudul Penerapan Metode Dakwah Mujadalah Dalam Membendung Radikalisme di Indonesia. ${ }^{14}$ Tulisan Priyanto mempunyai kesamaannya dengan tulisan ini yaitu membahas tentang mujadalah. Perbedaannya, tulisan ini fokus membahas mujadalah Nabi Ibrahim, sedangkan tulisan Priyanto membahas tentang metode mujadalah sebagai alat membendung radikalisme. Teori yang digunakan juga berbeda yaitu teori argumentasi Toulmin, sedangkan Priyanto menggunakan teori metode dakwah mujadalah dan radikalisme. Dengan demikian, tulisan ini berbeda dengan tulisan Priyanto.

Studi berikutnya, Metode Pengajaran Tauhid Nabi Ibrahim AS, tulisan Fahri tersebut membahas tentang metode Nabi Ibrahim dalam mengajarkan tauhid kepada masyarakatnya. ${ }^{15}$ Persamaannya adalah metode yang dibahas adalah metode mujadalah, dan ayat yang dianalisis adalah QS. Al-Anbiya':51-70. Perbedaannya antara lain, pendekatan yang digunakan tulisan ini adalah teori argumentasi Toulmin sedangkan tulisan Muhammad Fahri menggunakan teori penafsiran ayat,

${ }^{14}$ Agung Teguh Priyanto, "Penerapan Metode Dakwah Mujadalah Dalam Membendung Radikalisme Di Indonesia," Jurnal Inteleksia vol. 01, no. 02 (2020): 305-326. khususnya metode tafsir maudhu'i. Ayat yang dianalisis dalam tulisan Muhammad Fahri adalah QS. Al-Anbiya' ayat 51-70, sedangkan tulisan ini juga membahas beberapa ayat lainnya yang berkaitan dengan mujadalah Nabi Ibrahim, salah satunya menjaga prinsip dalam etika dakwah yakni tidak mengolok atau menghina berhala yang mereka sembah seperti di dalam QS. Al-An'am (6) ayat 108.

Terdapat satu judul jurnal penelitian yang hampir mirip, yakni jurnal yang berjudul Retorik al-Mujadalah Nabi Ibrahim dalam AlQur'an; ${ }^{16}$ Akan tetapi penelitian tersebut menggunakan teori pendalilan rasional dan pendalilan emosi, berbeda dengan tulisan ini yang menggunakan teori argumentasi khususnya perspektif Toulmin untuk mengidentifikasi pola argumentasi yang digunakan dalam mujadalah Nabi Ibrahim. Dengan memahami pola argumentasinya, akan bisa ditarik sebuah prinsip pola argumentasi dalam mujadalah dakwah yang baik sesuai dengan pola argumentasi yang dilakukan oleh Nabi Ibrahim. Hal ini bisa menjadi pelajaran bagi para komunikator dakwah ketika hendak membangun argumentasi dakwahnya saat akan bermujadalah. Sehingga temuan yang diharapkan bisa dihasilkan dari penelitian ini bisa lebih dalam lagi berkaitan dengan kekhasan argumentasi mujadalahnya Nabi Ibrahim.

Sedangkan dalam hal kesamaan pada bagian pola argumentasi, ada beberapa tulisan yang membahas tentang pola argumentasi antara

\footnotetext{
${ }^{15}$ Muhammad Fahri, "Metode Pengajaran Tauhid Nabi Ibrahim AS", Jurnal At-Ta'dib vol. 1, no. 3 (2015): 266286.

${ }^{16}$ Nor Raudah Hj Siren, et. al., "Retorik al-Mujadalah Nabi Ibrahim dalam Al-Qur'an," International Journal of Quranic Research vol. 8, issue 1 (2016): 73-90.
} 
lain: 1) Pola Argumentasi Kabinet Kerja dalam Membentuk Reputasi dan Branding di tahun 2014; ${ }^{17}$ 2) Pola Argumen Paragraf Argumentatif Pada Artikel Jurnal Terakreditasi Bidang Ekonomi (Perspektif Stephen Toulmin). ${ }^{18}$ Dari penelitian tentang Pola Argumentasi di atas, kesamaan dengan tulisan ini yaitu pada pendekatan teori yang digunakan. Perbedaannya pada tulisan tentang pola argumentasi tersebut tidak membahas mujadalah Nabi Ibrahim. Bahkan tulisan tentang pola argumentasi yang berkaitan dengan mujadalah, atau dakwah Islam, hanya ditemukan pada tulisan jurnal Siren et.al. Sehingga dari berbagai penelusuran terhadap studi terdahulu, menunjukkan bahwa tulisan ini adalah tulisan yang baru dan belum ada yang meneliti sebelumnya. Selain aspek kebaruan, terdapat aspek yang menarik dari penelitian ini yakni yang dikaji bukan hanya membahas pola argumentasi dalam debat, tapi yang dipahami adalah pola argumentasi debatnya Nabi Ibrahim dalam Al-Qur'an. Tentunya hal ini akan memberikan pelajaran yang besar bagi para dai (komunikator dakwah). Sebab dengan memahaminya, sangat bermanfaat untuk pijakan dalam membangun argumentasi yang kuat dan tidak bisa dibantah oleh lawan debat dalam menerapkan metode dakwah mujadalah atau debat.

Rumusan masalah dalam tulisan ini yakni bagaimanakah pola argumentasi mujadalah Nabi Ibrahim dengan ayahnya, masyarakatnya, dan Raja Namrud?. Tujuan tulisan ini ingin mengetahui pola

\footnotetext{
17 Dina Safitri, "Pola Argumentasi Kabinet Kerja dalam Membentuk Reputasi dan Branding di 2014," Conference: Konferensi Nasional Komunikasi Pariwisata dan Kewirausahaan FIKOM UNSAHID: Tata Kelola Komunikasi Kewirausahaan di Bogor (2015): 421-442.
}

argumentasi dalam mujadalah Nabi Ibrahim dengan ayahnya, masyarakatnya dan Raja Namrud. Metode yang digunakan dalam menjawab rumusan masalah ini adalah metode kualitatif dengan model analisis teks menggunakan pendekatan teori argumentasi. Penelitian ini termasuk termasuk penelitian kualitatif karena bertujuan untuk memahami fenomena yang dialami oleh subjek penelitian secara utuh dan dengan cara mendeskripsikan data yang bukan angka tapi kata-kata atau kalimat yang kemudian dianalisis untuk menjawab rumusan masalah. ${ }^{19}$ Metode pengumpulan datanya dengan studi pustaka, yakni mengambil data dari mujadalah yang dilakukan Nabi Ibrahim yang terdapat dalam teks Al-Qur'an. Metode pencarian data dan analisis data tulisan ini adalah dengan mencari data tentang Nabi Ibrahim dalam AlQur'an, kemudian dari data tersebut, diambil data yang menunjukkan mujadalah atau debat yang dilakukan oleh $\mathrm{Nabi}$ Ibrahim, terutama mujadalah Nabi Ibrahim dengan ayahnya, dengan masyarakatnya, dan dengan Raja Namrud. Setelah itu menganalisis data tentang mujadalah tersebut menggunakan teori argumentasi Toulmin, terakhir ditarik kekhasan atau pola argumentasi mujadalah Nabi Ibrahim dengan ayahnya, masyarakatnya dan Raja Namrud.

\footnotetext{
18 Yuliana Setianingsih. "Pola Argumen Paragraf Argumentatif Pada Artikel Jurnal Terakreditasi Bidang Ekonomi (Perspektif Stephen Toulmin)," Jurnal Adabiyat vol. 15, no. 2 (2016): 136-156.

19 Lexy J. Moleong, Metodologi Penelitian KualitatifEdisi Revisi (Bandung: PT. Remaja Rosdakarya,2015), 6.
} 


\section{Pengertian Argumentasi Mujadalah}

Untuk memahami pola argumentasi mujadalah, perlu didalami dahulu tentang mujadalah. Sehingga dari pemahaman tersebut akan dapat diketahui kedudukan argumentasi dan fungsinya dalam mujadalah, dan memahami pola argumentasinya.

Al-Mujadalah berdasarkan Al-Qur'an dan sunah adalah jadal, yakni menggunakan dalil yang lengkap dan kuat sehingga bisa diterima dan menarik hati manusia. ${ }^{20}$ Menurut Manna' al-Qathan dalam bukunya berjudul Mabahits fi 'Ulumil Qur'an menyatakan bahwa jadal atau jidal adalah bertukar pikiran dengan cara bersaing dan berlomba untuk mengalahkan lawan. ${ }^{21}$ Dari pengertian tersebut secara prinsip mujadalah dapat diidentikkan dengan debat.

Dalam Kamus Besar Bahasa Indonesia kata debat diartikan pembahasan dan pertukaran pendapat mengenai suatu hal dengan saling memberi alasan untuk mempertahankan pendapat masing-masing; debat kusir debat yang tidak disertai alasan yang masuk akal. ${ }^{22}$ Dalam pengertian yang lain debat adalah suatu pembahasan atau pertukaran pendapat mengenai suatu pokok masalah, masing-masing peserta memberikan alasan untuk mempertahankan pendapatnya. ${ }^{23}$ Sedangkan Hendrikus menyampaikan bahwa debat pada hakikatnya merupakan saling adu argumentasi antarpribadi atau antarkelompok manusia, dengan tujuan

20 Nor Raudah $\mathrm{Hj}$ Siren, et. al, Retorik al-Mujadalah Nabi Ibrahim dalam Al-Qur'an, 74.

21 Manna' al-Qathan, Mabahits fi 'ulumil qur'an, (Riyadl: Mansyuratal-'Ashrial-Haditsah,tt), 298.

${ }^{22}$ Kamus Besar Bahasa Indonesia Online, diakses tanggal 26 April 2020. https://kbbi.web.id/debat, . mencapai kemenangan untuk suatu pihak. Ketika berdebat setiap pribadi atau kelompok mencoba untuk saling menjatuhkan agar pihaknya berada pada posisi yang benar. ${ }^{24}$

Dari berbagai pengertian di atas, ada beberapa prinsip dalam Mujadalah, yakni: 1) Suatu debat dilatarbelakangi oleh adanya perbedaan bahkan pertentangan pendapat di antara dua belah pihak atau lebih, baik individu atau kelompok; 2) Tujuannya bagi yang berdebat ingin menunjukkan keunggulan pendapatnya dan menunjukkan kelemahan pendapat lawan dan ingin mendapatkan dukungan sebanyak mungkin dari audiens. Bagi audiens yang melihat debat ingin mengetahui pendapat terbaik dari suatu topik atau masalah yang diperdebatkan.

Dalam suatu mujadalah atau debat, kualitas argumen mempunyai pengaruh sangat signifikan untuk memengaruhi audiens. Menurut Shihab, mujadalah yang baik sesuai dengan perintah Allah dalam QS. An-Nahl ayat 125 adalah debat yang disampaikan dengan cara yang baik, didukung dengan argumentasi yang benar lagi dapat membungkam pendapat lawan debat. ${ }^{25}$ Sehingga mujadalah yang baik salah satu cirinya adalah didukung oleh argumen yang benar dan kuat. Sebaliknya mujadalah yang buruk adalah debat yang tidak didukung oleh argumen yang kuat.

\footnotetext{
23 JS. Kamdhi, Diskusi Yang Efektif (Cirebon : Kanisius, 1995), 24-26.

24 Dori Wuwur Hendrikus, Retorika Terampil Berpidato, Berdiskusi, Berargumentasi, Bernegoisasi (Yogyakarta: Kanisius, 2005), 120.

${ }^{25}$ M. Quraish Shihab, Tafsir Al-Mishbah, Pesan, Kesan dan Keserasian al-Qur'an, 776.
} 
Dalam Kamus Besar Bahasa Indonesia, argumentasi diartikan alasan untuk memperkuat atau menolak suatu pendapat, pendirian, atau gagasan. ${ }^{26}$ Menurut Keraf argumentasi adalah suatu bentuk retorika yang dibangun agar bisa memengaruhi sikap dan pendapat orang lain, agar orang lain percaya dan bertindak sesuai dengan apa yang diinginkan oleh orang yang menyampaikan argumentasi. ${ }^{27}$ Argumentasi dibangun oleh evidence atau bukti-bukti yang berasal dari data dan fakta, yang dihubungkan oleh penalaran menjadi suatu kesatuan proposisi.

Argumen adalah sebuah pernyataan yang berisikan sebuah claim, dan adanya dukungan yang memperkuat dalam rangka memengaruhi orang lain dalam konteks ketidaksetujuan. $^{28} \quad$ Menurut Ennis, "argument is an attempt to prove or establish a conclusion. It has two major parts: a conclusion and the reason or reasons offered in support of the conclusion (argumen adalah suatu upaya untuk membuktikan atau membangun kesimpulan. Di dalamnya terdapat dua bagian yakni kesimpulan didukung oleh alasan atau alasan yang digunakan untuk mendukung kesimpulan)."29

Untuk memahami argumentasi mujadalah/debat, seseorang bisa menggunakan teori dari Toulmin. Teori argumentasi Toulmin ini dipilih karena tidak hanya mengidentifikasi argumentasi, tapi juga dapat mengidentifikasi struktur

\footnotetext{
${ }^{26}$ Kamus Besar Bahasa Indonesia Online, diakses 26 April 2020. https://kbbi.web.id/argumentasi,

27 Gorys Keraf, Argumentasi dan Narasi, 3.

28 Edward S. Inch, Barbara Warnick, and Danielle Endres, Critical Thinking and Communication: The Use of Reason in Argument (Boston: Pearson Education, Inc., 2006), 9.
}

argumentasinya. Selain itu, akan dianalisis juga dengan pendekatan komunikasi, di mana pesan berupa pola argumentasi yang dibangun akan dianalisis konteks situasi dan kondisi komunikan dakwahnya. Sehingga dengan menggunakan teori argumentasi Toulmin, akan dapat dipahami sampai pada pola atau struktur argumentasi mujadalah Nabi Ibrahim dalam mendakwahkan Islam kepada ayahnya, masyarakatnya dan Raja Namrud, sekaligus bisa dipahami alasannya mengapa menggunakan pola argumentasi seperti itu. Sehingga bisa diamati polanya lebih dalam, jika bermujadalah dengan seorang ayah atau personal pola argumentasinya seperti apa, jika bermujadalah dengan orang yang jumlahnya banyak atau masyarakat luas menggunakan pola argumentasi seperti apa, dan jika berhadapan dengan penguasa menggunakan pola argumentasi seperti apa.

\section{Elemen Argumentasi Dalam Mujadalah}

Menurut Toulmin, argumentasi bagaikan organisme, yang mana antara satu bagian saling berpengaruh dengan bagian yang lain. ${ }^{30}$ Menurut Toulmin dalam Gustira, ada enam elemen dalam membangun dan menguatkan suatu argumen secara eksplisit. Keenam elemen argumen tersebut antara lain: claim, ground, warrant, backing, modal qualifiers, dan rebuttal. Tiga elemen yang pertama (claim, ground, dan warrant) adalah elemen utama membangun suatu argumen, sedangkan tiga elemen berikutnya

\footnotetext{
29 Robert H. Ennis, Critical Thinking (New Jersey: Prentice Hall, Inc., 1996), 2.

30 Stephen Toulmin, The Uses Argumentation, Update Edition (New York: Cambridge University Press, 2003), 87.
} 
(backing, modal qualifiers, dan rebuttal) merupakan elemen penunjang yang menguatkan argumen. ${ }^{31}$

Claim merupakan pernyataan yang diyakini kebenarannya oleh komunikator mujadalah. Claim yang bentuknya sebuah pernyataan menunjukkan posisi komunikator dalam suatu komunikasi debat, apakah pernyataannya pro atau kontra terhadap suatu topik permasalahan. Claim merupakan pernyataan komunikator debat yang bisa ditolak atau diterima kebenarannya oleh orang lain. Oleh karena itu pernyataan yang terdapat dalam claim perlu diperkuat dengan bukti-bukti berupa fakta, data, dan penunjang argumentasi lainnya. Sebab jika dalam suatu debat hanya ada pernyataan atau claim saja, maka akan dengan mudah ditolak atau tidak dipercaya oleh orang lain.

Untuk memperkuat pernyataan dalam suatu claim, maka pernyataan atau claim diperkuat dengan didukung oleh (ground/G) yang berisi bukti-bukti berupa data atau fakta untuk memperkuat claim. Ground akan makin kuat apabila ditambahkan dengan jaminan (warrant/W). Warrant ini merupakan suatu pernyataan yang menjadi penghubung antara claim dan ground. Struktur argumen yang berisi claim, warrant dan ground menunjukkan bangunan argumentasi yang utuh dan cukup kuat. Namun, untuk memperkuat bangunan argumentasi agar tidak bisa dijatuhkan dalam debat, dibutuhkan bukti pendukung yang memperkuat warrant. Bukti pendukung yang memperkuat ini dinamakan

31 Yinda Dwi Gustira, "Argumentasi Dalam Skripsi Mahasiswa S-1 Fakultas Kedokteran Universitas Lampung Tahun 2015 Dan Implikasinya Dalam Pembelajaran Logika Pada PS-PBSI FKIP Universitas Lampung," (Thesis Program Pascasarjana, Universitas Lampung, 2016), 16. backing (B). Akan tetapi ketika claim mengandung kemungkinan tertentu, nantinya dapat muncul modal qualifier (Q). Selain bertahan, seorang komunikator debat/mujadalah juga dapat melakukan serangan ke argumen lawan debatnya, sehingga muncul rebuttal (R), yakni penolakan atas argumentasi lawan. ${ }^{32}$

\section{Pola Argumentasi Mujadalah}

Suatu argumentasi juga mempunyai pola atau struktur. Karena merupakan suatu kesatuan struktur bangunan pemikiran. Pola argumentasi dalam suatu debat, dapat diamati secara langsung dari struktur argumentasi mujadalah. Apalagi jika yang diamati lebih dari satu kali kasus mujadalah, pola akan dapat ditemukan dari kekhasan argumentasi yang disampaikan oleh seorang komunikator debat.

Toulmin dalam Febriyanti membagi pola argumentasi menjadi 5 jenis. Pola tersebut tersusun dari 6 elemen argumentasi, antara lain claim, ground, warrant, backing, modal qualifier, dan rebuttal. Pola argumentasi tersebut antara lain: (1) Pola pertama, argumen yang menggunakan unsur claim (pernyataan) dan ground (bukti) saja. Ini merupakan susunan pola argumen paling sederhana; (2) Pola kedua, argumen yang menggunakan elemen claim (pernyataan), ground (bukti), dan warrant (penjamin); (3) Pola ketiga, argumen yang dibangun dari elemen claim (pernyataan), ground (bukti), warrant (jaminan), dan backing (bukti penguat); (4) Pola keempat, argumen yang

${ }^{32}$ Beby Dwi Febriyanti, "Argumentasi Pada Teks Pidato Siswa Kelas XSMA Negeri I Rambipuji," AL-ASHR: Jurnal Pendidikan Dan Pembelajaran Dasar, Prodi PGMI-FAIUniversitas Islam Jember vol. 2, no. 1 (2017): 4. 
dibangun oleh elemen claim (pernyataan), ground (bukti), warrant (penjamin), backing (bukti penguat) dan modal qualifier (kemungkinan tertentu); (5) Pola kelima, yakni argumen yang dibangun dari unsurunsur memuat keenam elemen argumentasi secara lengkap, yakni claim (pernyataan), ground (bukti), warrant (penjamin), backing (bukti penguat), modal qualifier (kemungkinan tertentu), dan rebuttal (serangan). ${ }^{33}$ makin lengkap elemen argumentasi, mengindikasikan bahwa argumentasi tersebut makin kuat.

Studi ini akan mengidentifikasi pola argumentasi mujadalah Nabi Ibrahim berdasarkan lima pola atau struktur argumentasi tersebut.

\section{Argumentasi Mujadalah Nabi Ibrahim}

Dalam mengenalkan tauhid, Nabi Ibrahim menggunakan metode mujadalah. Hal ini dilakukan karena masyarakat saat itu mempunyai pemikiran yang berbeda bahkan bertolak belakang dengan pemikiran dan keyakinan Nabi Ibrahim yang melakukan dakwahnya dengan terbuka. Tentunya dengan kondisi yang seperti itu tidak bisa meyakinkan mereka hanya dengan satu arah lewat metode dakwah ceramah saja. Perlu dialektika dalam bentuk mujadalah. Jika mereka mau berpikir rasional maka dialektika mujadalah itu akan berjalan lancar menjadi sebuah diskusi tentang ketuhanan untuk mencari Tuhan yang benar. Akan tetapi ketika kondisi masyarakatnya menolak dan menganggap keyakinan yang bertentangan dengan mereka adalah sebuah kesesatan, maka mujadalah itu akan menjadi

33 Ibid. sebuah ajang pembuktian kebenaran pendapat, sehingga menjadi sebuah proses debat. Dalam Al-Qur'an dijelaskan bahwa Nabi Ibrahim bermujadalah atau berdebat dengan ayahnya, dengan masyarakatnya, juga dengan Raja Namrud yang terkenal otoriter dan kejam saat itu. Di dalam mujadalah tersebut, kita akan mengetahui bagaimana argumentasi yang disampaikan oleh Nabi Ibrahim.

Argumentasi mujadalah Nabi Ibrahim dengan ayahnya terdapat dalam beberapa ayat Al-Qur'an. Seperti dalam QS. Al-An'am ayat 74 :

"Dan (ingatlah) di waktu Ibrahim berkata kepada ayahnya Azar, "Pantaskah engkau menjadikan berhala-berhala itu sebagai Tuhan? Sesungguhnya aku melihat engkau dan kaummu dalam kesesatan yang nyata. ${ }^{134}$

Juga terdapat dalam QS. Maryam ayat 4248:

"(Ingatlah) ketika dia (Ibrahim) berkata kepada ayahnya; "Wahai ayahku! Mengapa engkau menyembah sesuatu yang tidak mendengar, tidak melihat, dan tidak dapat menolong kamu sedikitpun?. Wahai ayahku! Sungguh, telah sampai kepadaku sebagian ilmu yang tidak diberikan kepadamu, maka ikutilah aku, niscaya aku akan menunjukkan kepadamu jalan yang lurus. Wahai ayahku! Janganlah engkau menyembah setan. Sungguh setan itu durhaka kepada Tuhan Yang Maha Pengasih. Wahai ayahku! Sungguh aku khawatir engkau akan ditimpa azab dari Tuhan Yang Maha Pengasih, sehingga engkau menjadi teman bagi setan." Dia (ayahnya) berkata: "Bencikah kamu kepada Tuhan-tuhanku, hai Ibrahim?

\footnotetext{
34 Departemen Agama RI, Al-Qur'an dan Terjemahannya, 184.
} 
Jika engkau tidak berhenti, pasti engkau akan kurajam, dan tinggalkanlah aku untuk waktu yang lama." Dia (Ibrahim) berkata: "Semoga keselamatan dilimpahkan kepadamu, aku akan memohonkan ampun bagimu kepada Tuhanku. Sesungguhnya Dia sangat baik kepadaku. Dan aku akan menjauhkan diri darimu dan dari apa yang engkau sembah selain Allah, dan aku akan berdoa kepada Tuhanku, mudah-mudahan aku tidak akan kecewa dengan berdoa kepada Tuhanku." ${ }^{\prime 35}$

Selain bermujadalah atau berdebat dengan ayahnya, Nabi Ibrahim juga bermujadalah atau berdebat dengan umatnya. Argumentasi mujadalah Nabi Ibrahim dengan umatnya dapat kita amati dalam QS. Al-An'am ayat 80-83:

"Dan kaumnya membantahnya. Dia (Ibrahim) berkata: "Apakah kamu hendak membantahku tentang Allah, padahal Dia benar-benar telah memberi petunjuk kepadaku? Aku tidak takut kepada (malapetaka dari) apa yang kamu persekutukan dengan Allah, kecuali Tuhanku menghendaki sesuatu. IImu Tuhanku meliputi segala sesuatu. Tidakkah kamu tidak dapat mengambil pelajaran?" Bagaimana aku takut kepada apa yang kamu persekutukan (dengan Allah), padahal kamu tidak takut dengan apa yang Allah sendiri tidak menurunkan keterangan kepadamu untuk mempersekutukan-Nya. Manakah dari kedua golongan itu yang lebih berhak mendapat keamanan (dari malapetaka), jika kamu mengetahui?. Orang-orang yang beriman dan tidak mencampuradukkan iman mereka dengan syirik, mereka itulah orang-orang yang mendapat rasa aman dan mereka mendapat

35 Ibid., 423-424 petunjuk. Dan itulah keterangan Kami yang Kami berikan kepada Ibrahim untuk menghadapi kaumnya. Kami tinggikan derajat siapa yang Kami kehendaki. Sesungguhnya Tuhanmu Mahabijaksana, Maha Mengetahui. ${ }^{36}$

Allah juga menjelaskan dinamika mujadalah serta argumentasi yang digunakan Nabi Ibrahim ketika bermujadalah dengan masyarakatnya dalam QS. Al-Anbiya' ayat 51-71:

"(Ingatlah), ketika Ibrahim berkata kepada ayahnya dan kaumnya: "Patung-patung apakah ini yang kamu tekun menyembahnya?" Mereka menjawab: "Kami mendapati nenek moyang kami menyembahnya." Dia (Ibrahim) berkata: "Sesungguhnya kamu dan nenek moyangmu berada dalam kesesatan yang nyata." Mereka berkata: "Apakah engkau datang kepada kami membawa kebenaran atau engkau main-main?" Dia (Ibrahim) berkata: "Sebenarnya Tuhan kamu ialah Tuhan (pemilik) langit dan bumi. (Dialah) yang telah menciptakannya; dan aku termasuk orang yang dapat bersaksi atas itu." Dan demi Allah, Sungguh, aku akan melakukan tipu daya terhadap berhala-berhalamu setelah kamu pergi meninggalkannya. Maka dia (Ibrahim) menghancurkan (berhalaberhala itu) berkeping-keping, kecuali yang terbesar (induknya); agar mereka kembali (untuk bertanya) kepadanya. Mereka berkata: "Siapakah yang melakukan (perbuatan) ini terhadap Tuhan-tuhan kami, Sungguh, dia termasuk orang yang zalim." Mereka (yang lain) berkata: "Kami dengar ada seorang pemuda yang mencela (berhala-berhala ini), namanya Ibrahim." Mereka berkata: "(Kalau demikian) bawalah

${ }^{36}$ Ibid., 185 
dia dengan diperlihatkan kepada orang banyak, agar mereka menyaksikan." Mereka bertanya: "Apakah engkau, yang melakukan (perbuatan) ini terhadap Tuhan-tuhan kami, wahai Ibrahim?" Dia (Ibrahim) menjawab: "Sebenarnya (patung) besar itu yang melakukannya, maka tanyakanlah kepada mereka, jika mereka dapat berbicara." Maka mereka kembali kepada kesadaran mereka dan berkata: "Sesungguhnya kamulah yang menzalimi (diri sendiri)". Kemudian mereka menundukkan kepala (lalu berkata): "Engkau (Ibrahim) pasti tahu bahwa (berhala-berhala) itu tidak dapat berbicara." Dia (Ibrahim) berkata: Mengapa kamu menyembah selain Allah, sesuatu yang tidak dapat memberi manfaat sedikitpun, dan tidak (pula) mendatangkan mudarat kepada kamu?" Celakalah kamu dan apa yang kamu sembah selain Allah! Tidakkah kamu mengerti?" Mereka berkata: "Bakarlah dia dan bantulah Tuhan-tuhan kamu, jika kamu benar-benar hendak berbuat." Kami (Allah) berfirman: "Wahai api! jadilah kamu dingin, dan penyelamat bagi Ibrahim", mereka hendak berbuat jahat terhadap Ibrahim, maka Kami menjadikan mereka itu orangorang yang paling rugi. Dan Kami selamatkan dia (Ibrahim) dan Luth ke sebuah negeri yang Kami berkahi untuk seluruh alam." ${ }^{137}$

Selain bermujadalah dengan ayahnya dan masyarakatnya. Nabi Ibrahim juga mempunyai keberanian menyampaikan nilai-nilai tauhid menggunakan metode mujadalah dengan Raja Namrud bin Kan'an yang terkenal otoriter. Dari proses mujadalah tersebut, kita dapat mengetahui argumentasi Nabi Ibrahim saat berdebat dengan Raja Namrud. Allah menceritakan

37 lbid, 455-456. peristiwa perdebatan tersebut dalam QS. AlBaqarah ayat 258:

"Tidakkah kamu memperhatikan orang yang mendebat Ibrahim mengenai Tuhannya, karena Allah telah memberinya kerajaan (kekuasaan). Ketika Ibrahim berkata: "Tuhanku ialah Yang menghidupkan dan mematikan," dia berkata: "Akupun dapat menghidupkan dan mematikan." Ibrahim berkata: "Allah menerbitkan matahari dari timur, maka terbitkanlah ia dari barat," lalu bingunglah orang kafir itu; Allah tidak memberi petunjuk kepada orang-orang yang zalim." ${ }^{\prime 38}$.

Memang dari ayat tersebut di atas, tidak menunjukkan adanya perubahan pemikiran dari objek dakwah Nabi Ibrahim, yakni ayahnya, masyarakatnya, dan Raja Namrud. Sebab dalam debat tersebut, masing-masing orang yang terlibat di dalamnya sudah punya keyakinan yang melekat yang sangat sulit dirubah, dan mereka tidak mau terbuka secara pemikiran untuk mencari kebenaran dengan tetap memegang tradisi penyembahan patung. Namun, di dalam mujadalah atau debat yang menjadi poin pentingnya adalah adanya keunggulan argumentasi yang berupa bukti-bukti kuat yang tidak bisa dilawan oleh lawan debat serta cara penyampaiannya yang baik, bukan pada perubahan pemikiran lawan debat. Sasaran utama dalam debat adalah audiens yang masih terbuka pemikirannya untuk menilai secara objektif.

Dari argumentasi dan bukti-bukti dalam peristiwa mujadalah Nabi Ibrahim tersebut mampu menunjukkan pernyataan Nabi Ibrahim bahwa yang layak disembah hanyalah Allah, didukung oleh bukti yang kuat dan tidak bisa dibantah, serta disertai penyampaian Nabi Ibrahim dengan cara yang baik. Sehingga Allah mengangkat

38 lbid., 53-54 
peristiwa mujadalah ini sebagai petunjuk tentang bagaimana realitas debat atau mujadalah yang seharusnya yang bisa dijadikan pembelajaran oleh umat Islam setelahnya.

\section{Pola Argumentasi Mujadalah Nabi Ibrahim dengan Ayahnya}

Mujadalah antara Ibrahim dan ayahnya terdapat dalam beberapa ayat, salah satunya QS. Maryam ayat 42-48. Melalui tafsir tematik, khususnya terkait mujadalah Nabi Ibrahim, tulisan ini hanya akan berfokus mengidentifikasi pola argumentasi beradasarkan kisah yang ada dalam nashnash Al-Qur'an tersebut. Sehingga tulisan ini tidak hendak menafsirkan teks ayatnya dengan menggunakan metode memahami ayat-ayat Allah, tapi difokuskan pada memahami pola argumentasi dalam mujadalah Nabi Ibrahim yang terdapat dalam teks Al-Qur'an tersebut. Teks ayat dalam QS. Maryam ayat 42-48 akan dianalisis menggunakan teori argumentasi Toulmin, sebab secara proses mujadalah lebih utuh, sedangkan ayat yang lain bersifat penguat analisis argumentasi mujadalah Nabi Ibrahim dengan ayahnya.

Nabi Ibrahim sejak kecilnya sudah hidup dalam lingkungan penyembah patung. Ayah Nabi Ibrahim adalah Azar (Tarih) bin Tahur bin Saruj bin Rau' bin Falij bin Aabir bin Syalih bin Arfakhsyaad bin Sam bin Nuh AS, seorang pembuat patung. ${ }^{39}$ Sehingga sejak kecil, Nabi Ibrahim memahami realitas penyembahan patung ini. Saat itu Nabi Ibrahim resah dengan keadaan masyarakatnya yang menyembah berhala. Keresahan itulah yang membuat dirinya

${ }^{39}$ Nor Raudah Hj Siren, et. al., Retorik al-Mujadalah Nabi Ibrahim dalam Al-Qur'an, 75-76. mencari Tuhan. Setelah Ibrahim menemukan siapa Tuhan yang layak disembah, Nabi Ibrahim mencoba untuk menyampaikan dakwah kepada ayahnya. Allah mengabadikan proses Nabi Ibrahim ketika berdakwah dengan ayahnya dengan metode mujadalah tersebut di QS. Maryam ayat $42-48$.

Dalam proses mujadalah dengan ayahnya. Nabi Ibrahim mengajukan pernyataan (claim) bahwa dirinya menolak Tuhan-tuhan (patung berhala) yang disembah oleh ayahnya tersebut. Hal itu didasarkan atas bukti (ground) bahwa Tuhan-tuhan yang disembah ayahnya tersebut tidak dapat mendengar, tidak dapat melihat dan tidak dapat menolong yang menyembahnya. Secara tidak langsung, dalam argumen tersebut terdapat penjamin (warrant) bahwa Tuhan yang seharusnya layak disembah adalah Tuhan yang Maha Mendengar, Maha Melihat dan dapat menolong hamba-Nya. Hal ini seperti yang terdapat dalam firman Allah dalam QS. Maryam ayat 42, "(Ingatlah) ketika dia (Ibrahim) berkata kepada ayahnya; "Wahai ayahku! Mengapa engkau menyembah sesuatu yang tidak mendengar, tidak melihat, dan tidak dapat menolong kamu sedikitpun?. ${ }^{40}$ Selain adanya pernyataan dan bukti, ayat tersebut menggunakan kalimat pertanyaan retorik yang secara tidak langsung memberikan serangan argumentasi (rebuttal) terhadap pemikiran dan perilaku ayahnya yang menyembah patung. Disinilah kita melihat keunikannya, ada empat elemen argumentasi dalam satu bangunan paragraf ayat di atas yang berisi dua kalimat.

\footnotetext{
40 Departemen Agama RI, Al-Qur'an dan Terjemahannya, 423
} 
Selanjutnya Nabi Ibrahim mengajukan alasan untuk mendukung asumsinya atau backing, agar ayahnya mau mengikuti argumentasinya. Hal ini bisa dilihat dalam QS. Maryam ayat 43, dengan kalimat, Wahai ayahku! Sungguh, telah sampai kepadaku sebagian ilmu yang tidak diberikan kepadamu, maka ikutilah aku, niscaya aku akan menunjukkan kepadamu jalan yang lurus. " ${ }^{\prime 11}$ Kalimat ajakan Nabi Ibrahim kepada ayahnya agar mengikutinya tersebut disertai dukungan alasan atau backing bahwa Nabi Ibrahim mempunyai pengetahuan yang tidak dimiliki oleh ayahnya. Kemudian Nabi Ibrahim juga menguatkan dengan menyampaikan batasan atau modal qualifier (Q), jika ayahnya mengikutinya maka akan mendapati jalan yang lurus, jalan yang benar. Sebaliknya, jika tidak mengikutinya maka akan terjerumus ke jalan yang salah atau tersesat.

Selanjutnya Nabi Ibrahim mengajak ayahnya agar tidak mengikuti ajakan setan, beserta alasan pendukungnya. Uniknya kalimat ajakan ini langsung disampaikan dengan pilihan argumentasi rebuttal atau serangan. Bisa dilihat dalam di QS. Maryam ayat 44-45 dengan kalimat, "Wahai ayahku! Janganlah engkau menyembah setan. Sungguh setan itu durhaka kepada Tuhan Yang Maha Pengasih. Wahai ayahku! Sungguh aku khawatir engkau akan ditimpa azab dari Tuhan Yang Maha Pengasih, sehingga engkau menjadi teman bagi setan." 42 Kalimat ajakan tersebut dalam argumen Toulmin bisa dimasukkan sebagai back up argumen yang mendukung alasan-alasan yang ada. Pola serangan atau rebuttal juga ditunjukkan dengan menyatakan setan dan kalimat ancaman akhirat yakni adanya azab

41 lbid., 423-424.

42 Ibid., 424. jika tidak mengikuti pendapat Nabi Ibrahim. ini merupakan suatu keunikan, di mana bentuk backing alasan sekaligus rebuttal atau serangan dalam satu pernyataan.

Mendapatkan serangan argumen tersebut, ayahnya Nabi Ibrahim kemudian menjawabnya dalam QS. Maryam ayat 46 dengan berkata, Dia (ayahnya) berkata: "Bencikah kamu kepada Tuhan-tuhanku, hai Ibrahim? Jika engkau tidak berhenti, pasti engkau akan kurajam, dan tinggalkanlah aku untuk waktu yang lama." ${ }^{\prime 43}$ Kalimat ini menunjukkan bahwa ayahnya Nabi Ibrahim menjawab serangan Nabi Ibrahim dengan argumen berupa pernyataan (claim) dalam bentuk pertanyaan retorik, bencikah kamu terhadap Tuhan-tuhanku wahai Ibrahim? Pernyataan ini sebenarnya tidak menjawab apa-apa terhadap serangan Nabi Ibrahim, sebab Nabi Ibrahim menyerang pemikiran bahwa patung tidak layak dijadikan Tuhan kerena tidak memenuhi karakteristik sebagai Tuhan, patung yang dijadikan Tuhan tersebut tidak bisa melihat, mendengar apalagi memberikan pertolongan kepada yang menyembahnya, ternyata tidak dijawab. Pernyataan (claim) yang dinyatakan oleh ayahnya ini jelas pernyataan yang tidak didukung oleh bukti (ground) yang kuat, pernyataan ini hanya didasarkan pada penjamin (warrant) yakni menganggap bahwa Nabi Ibrahim mempunyai kebencian terhadap Tuhan-tuhannya.

Selanjutnya ayah Nabi Ibrahim memberikan argumen serangan (rebuttal), yakni jika masih mendebat atau terus-terusan memberikan argumen untuk melemahkan Tuhan-tuhan yang disembah ayahnya, maka ayahnya akan merajamnya, bahkan

43 Ibid., 424. 
mengusirnya jauh-jauh. Hal ini membuktikan bahwa ayahnya Nabi Ibrahim tidak bisa menjawab dan menyerang balik dalam bentuk argumentasi, tapi caranya adalah dengan ancaman fisik dan pengusiran, ini dilakukan sebab kalau melawan menggunakan argumentasi bisa kalah.

Kalau dibandingkan dengan serangan ancaman yang disampaikan Nabi Ibrahim, memang Nabi Ibrahim memberikan ancaman terhadap lawan debat, tapi ancaman itu ancaman akhirat yang tidak langsung fisik, selanjutnya disertai dengan ungkapan yang positif bahwa Nabi Ibrahim benar-benar ingin mengajaknya ke jalan yang lurus, ini berbeda dengan ancaman yang diberikan oleh ayah Nabi Ibrahim, yang mengancam akan dirajam, rajam merupakan hukuman fisik yang sangat berat sampai meninggal dunia, juga ancaman pengusiran, ini semua menunjukkan bahwa berbeda antara pola serangan Nabi Ibrahim dengan pola serangan yang dibangun ayahnya dalam mujadalah tersebut.

Selanjutnya Nabi Ibrahim menanggapi dengan pernyataan yang tenang. Dalam QS. Maryam ayat 47 Allah berfirman yang artinya, "Dia (Ibrahim) berkata: "Semoga keselamatan dilimpahkan kepadamu, aku akan memohonkan ampun bagimu kepada Tuhanku. Sesungguhnya Dia sangat baik kepadaku. Dan aku akan menjauhkan diri darimu dan dari apa yang engkau sembah selain Allah, dan aku akan berdoa kepada Tuhanku, mudah-mudahan aku tidak akan kecewa dengan berdoa kepada Tuhanku." ${ }^{\prime 44}$ Walaupun Nabi Ibrahim diancam akan dirajam, dan diusir oleh ayahnya, Nabi Ibrahim tidak membalasnya dengan argumen yang kasar, atau kata-kata yang buruk. Justru Nabi Ibrahim walaupun menyadari bahwa argumen ayahnya lemah, ayahnya tidak menjawab serangan argumen Nabi Ibrahim, walaupun ayahnya mengancam, Nabi Ibrahim masih menjawabnya dengan kalimat doa, kalimat bil hikmah serta menunjukkan kepada ayahnya bahwa Tuhannya Nabi Ibrahim adalah Tuhan Yang Maha Pemurah. Inilah pelajaran berharga bagi umat Islam, bahwa ketika bermujadalah, walaupun diberikan pernyataan yang kasar, kotor, doa yang buruk, sudah seharusnya tetap menjawabnya dengan bahasa yang baik. Hal ini mudah diucapkan tapi sukar dilakukan.

Dari analisis di atas, dapat dipahami bahwa argumen Nabi Ibrahim ketika bermujadalah dengan ayahnya menggunakan pola berupa pernyataan (claim) bahwa patung-patung tidak layak dijadikan sesembahan, kemudian menguatkan dengan bukti ground atau alasan, yakni berhala tersebut tidak dapat mendengar, melihat dan menolong hambaNya. Argumennya juga didukung oleh satu warrant atau penjamin bahwa Tuhan yang seharusnya adalah yang Maha Melihat, Maha Mendengar, dan Maha Penolong hamba-Nya. Selanjutnya ada modal qualifier yang dibangun antara lain dengan menyampaikan kalau mengikutinya maka akan menempuh jalan yang lurus. Nabi Ibrahim mengemasnya dengan menggunakan bahasa serangan, kemudian dilanjutkan dengan serangan kedua dan ketiga. Sedangkan ayahnya menjawabnya dengan satu alasan, kemudian disertai dengan serangan (rebuttal) berupa serangan ancaman rajam dan diusir. Dari proses argumentasi ini, dapat disimpulkan bahwa

${ }^{44}$ Ibid., 424. 
argumentasi Nabi Ibrahim lebih kuat dibandingkan dengan argumentasi ayahnya.

Kalau dianalisis dengan pola argumentasi Toulmin, ada keunikan dalam pola argumentasi dalam mujadalah Nabi Ibrahim. Di mana pola argumentasi awal Nabi Ibrahim menggunakan pola pernyataan (claim), bukti (ground), penjamin (warrant), serangan (rebuttal), kemudian jaminan (back up), kemudian prasyarat (modal qualifier), selanjutnya melakukan serangan lagi (rebuttal). Secara pola argumentasi, masuk dalam pola ke-5, yang menggambarkan bahwa elemen argumentasi Nabi Ibrahim lengkap, bahkan disertai serangan argumentasi (rebuttal) beberapa kali yang cukup tajam.

Dalam konteks komunikasi, walaupun Nabi Ibrahim mujadalahnya secara personal dengan ayahnya, beliau menggunakan pola argumentasi yang lengkap yakni pola ke-5. Dalam mujadalah tersebut Nabi Ibrahim bukan hanya menunjukkan argumentasinya dengan bukti-bukti yang kuat, tapi juga memberikan serangan pemikiran yang tajam, sampai ayahnya tidak bisa membantahnya. Hal ini disebabkan yang menjadi komunikan atau lawan debatnya yakni ayahnya sendiri, adalah seorang yang bekerja sebagai pembuat patung, dia tentunya mempunyai pemikiran dan pembelaan yang kuat terhadap kebiasaan penyembahan patung, sebab berkaitan dengan kepentingan ekonominya. Sehingga menghadapi ayahnya yang seperti itu, Nabi Ibrahim menggunakan pola yang ke-5. Dan terbukti, pola argumentasi Nabi Ibrahim tidak dapat dibantah, malah ayahnya mengancamnya akan mengusirnya.

45 Departemen Agama RI, Al-Qur'an dan Terjemahannya, 454-456.
Selanjutnya Nabi Ibrahim menggunakan pembuktian secara rasional, dengan menggunakan pendekatan sifat-sifat Allah. Bisa jadi hal ini dikarenakan ayahnya secara inteligensi dianggap dapat memahami pembuktian rasional tersebut. Dan juga memahami karakteristik patung yang selama ini dibuatnya yang memang sebenarnya tidak layak disembah. Sehingga digunakan pembuktian rasional.

\section{Pola Argumentasi Mujadalah Nabi Ibrahim dengan Masyarakatnya}

Dalam menganalisis argumentasi mujadalah Nabi Ibrahim dengan umatnya, terdapat dalam QS. Al-An'am ayat 80-86 sebagai data utama, sebab dalam ayat ini berisi argumentasi yang lebih utuh. Sedangkan ayat-ayat yang berada di surah lain, akan digunakan sebagai data pembandingnya.

Proses mujadalah atau perdebatan antara Nabi Ibrahim dengan masyarakatnya dalam QS. Al-Anbiya' ayat $51-71 .{ }^{45}$ Argumen pembuka Nabi Ibrahim dalam QS. AlAnbiya':52 berupa pertanyaan kepada umatnya, "(Ingatlah), ketika Ibrahim berkata kepada ayahnya dan kaumnya: "Patungpatung apakah ini yang kamu tekun menyembahnya?" Mereka menjawab: "Kami mendapati nenek moyang kami menyembahnya." ${ }^{\prime 46}$ Pertanyaan pembuka dari Nabi Ibrahim dalam ayat tersebut dijawab oleh umatnya bahwa mereka melakukan itu karena sudah menjadi tradisi atau kebiasaan masyarakatnya yakni menyembah berhala, mereka menganggap bahwa tradisi penyembahan patung ini

${ }^{46}$ Ibid., 454. 
sebagai kebenaran yang sudah dilakukan oleh bapak-bapak atau nenek moyang mereka dulunya, sudah menjadi tradisi turun temurun.

Mengetahui jawaban dari umatnya, kemudian Nabi Ibrahim memberikan argumentasinya. Dalam QS. Al-Anbiya' ayat 54 Allah berfirman yang artinya, "Dia (Ibrahim) berkata: "Sesungguhnya kamu dan nenek moyangmu berada dalam kesesatan yang nyata". ${ }^{47} \mathrm{Hal}$ ini menunjukkan bahwa Nabi Ibrahim langsung memberikan pernyataan (claim) yang menunjukkan posisinya tidak setuju dengan penyembahan berhala yang dilakukan oleh masyarakat saat itu. Pernyataan ini juga disampaikan dengan bahasa menyerang pemikiran masyarakatnya (rebuttal), dengan mengatakan bahwa mereka berada dalam kesesatan yang nyata, menurut Ibrahim kesesatan itu nyata karena patung-patung tersebut sudah nyata-nyata buatan manusia, tidak bisa melakukan apapun bahkan menyelamatkan diri mereka sendiri, malah dijadikan sesembahan, dimintai pertolongan, padahal menolong dirinya sendiri saja tidak bisa. Bagi Ibrahim itu adalah bentuk kesesatan yang nyata.

Serangan atau rebuttal Nabi Ibrahim tersebut tentunya memantik emosi masyarakatnya, karena secara umum tidak ada manusia yang diam saja ketika diserang dengan pernyataan bahwa mereka dianggap sesat. Masyarakat yang diajak mujadalah Nabi Ibrahim saat itu kemudian menjawab dalam QS. Al-Anbiya' ayat 55, Mereka berkata: "Apakah engkau datang kepada kami membawa kebenaran atau engkau

47 Ibid., 454.

48 lbid., 454.

49 Ibid., 454-455. main-main?"148 Argumen untuk mempertanyakan kesungguhan pernyataan Ibrahim tersebut, sungguh-sungguh atau hanya sekadar main-main ketika menyatakan bahwa masyarakat saat itu berada dalam kesesatan yang nyata.

Nabi Ibrahim kemudian memberikan jawaban terhadap mereka dalam QS. AlAnbiya' ayat 56, "Sebenarnya Tuhan kamu ialah Tuhan (pemilik) langit dan bumi. (Dialah) yang telah menciptakannya; dan aku termasuk orang yang dapat bersaksi atas itu." ${ }^{\prime 49}$ Di sini Nabi Ibrahim menjelaskan alasan (ground) atas pernyataan (claim) ajaran tauhid yang menolak penyembahan berhala. Bahwa Tuhan yang layak disembah adalah Tuhan pencipta langit dan bumi. Ground atau alasan ini dilandasi oleh jaminan atau warrant, bahwa sifat Tuhan yang seharusnya adalah pencipta alam semesta termasuk langit dan bumi. Argumen ini secara tidak langsung menjadi pembanding bagi argumen masyarakatnya yang menyembah patung yang diciptakan dan tidak bisa menciptakan apapun.

Dalam konsep pembuktian adanya Tuhan, salah satu bukti adalah bukti kosmologis. Bukti kosmologis menyatakan bahwa, di dunia ini setiap yang ada pasti ada sebabnya, dan sebab-sebab itu tentunya ada penggerak pertama yang menurut Aristoteles disebut sebagai Primum Mobile. Bagi orang yang percaya adanya Tuhan, maka Tuhan inilah yang disebut sebagai Primum Mobile atau pencipta dan penggerak awal alam semesta. ${ }^{50}$ Jika Tuhan yang seharusnya sebagai Primum Mobile adalah Tuhan yang menciptakan dan

\footnotetext{
50 Yusuf Suyono, "Bertuhan Tanpa Agama?," Jurnal
} Teologia vol. 22, no. 2 (2011): 9. 
mengatur gerak langit dan bumi, maka secara tidak langsung kalau dibandingkan dengan patung-patung yang menjadi sesembahan masyarakat saat itu, yang tidak bisa menciptakan apapun, malah dirinya diciptakan manusia, tentu patung itu tidak sesuai dengan sifat Tuhan yang seharusnya. Sehingga argumen Nabi Ibrahim ini meruntuhkan argumen masyarakatnya. Kemudian di akhir ayat tersebut, Nabi Ibrahim berjanji akan memberikan bukti atas proposisi yang disampaikannya.

Bukti yang diajukan oleh Nabi Ibrahim itu terdapat dalam QS. Al-Anbiya' ayat 57-61. "Dan Demi Allah, Sungguh, aku akan melakukan tipu daya terhadap berhalaberhalamu setelah kamu pergi meninggalkannya. Maka dia (Ibrahim) menghancurkan (berhala-berhala itu) berkeping-keping, kecuali yang terbesar (induknya); agar mereka kembali (untuk bertanya) kepadanya. Mereka berkata: "Siapakah yang melakukan (perbuatan) ini terhadap Tuhan-tuhan kami, Sungguh, dia termasuk orang yang zalim." Mereka (yang lain) berkata: "Kami dengar ada seorang pemuda yang mencela (berhala-berhala ini), namanya Ibrahim." Mereka berkata: "(Kalau demikian) bawalah dia dengan diperlihatkan kepada orang banyak, agar mereka menyaksikan."51 Dari ayat tersebut, menunjukkan bahwa Nabi Ibrahim memotong kepala patung-patung yang dijadikan sesembahan ini sebagai bukti (ground) dari argumentasi yang dijanjikan sebelumnya. Nabi Ibrahim menjadikan patung-patung ini sebagai alat bukti empiris untuk membuktikan kelemahan Tuhan yang berupa patung tersebut.

51 Departemen Agama RI, Al-Qur'an dan Terjemahannya, 455.
Ketika melihat kondisi patung yang kepalanya sudah dipenggal, tersisa hanya patung yang besar saja dengan membawa kapak. Masyarakatnya marah, dan memanggil Nabi Ibrahim. Ketika Nabi Ibrahim datang dan bertemu dengan orangorang tersebut, terjadilah proses mujadalah selanjutnya antara Nabi Ibrahim dengan masyarakatnya. Dalam QS. Al-Anbiya' ayat 62-63 Allah berfirman yang artinya, Mereka bertanya: "Apakah engkau, yang melakukan (perbuatan) ini terhadap Tuhan-tuhan kami, wahai Ibrahim?" Dia (Ibrahim) menjawab: "Sebenarnya (patung) besar itu yang melakukannya, maka tanyakanlah kepada mereka, jika mereka dapat berbicara." ${ }^{\prime 52}$ Dalam ayat ini Nabi Ibrahim tidak mengakui secara langsung kalau dirinya yang memotong kepala patung-patung yang disembah, malah menyampaikan kalau yang memotong itu adalah patung yang paling besar dan memegang kapak. Nabi Ibrahim juga menyuruh masyarakatnya saat itu untuk bertanya secara lisan kepada patung yang besar. Secara rasional tentu hal ini tidak bisa diterima oleh akal sehat, mana mungkin patung bisa melakukan perilaku seperti itu, mana mungkin juga patung bisa menjawab pertanyaan ketika ditanyai oleh manusia.

Allah kemudian menjelaskan dalam QS. AlAnbiya' ayat 64-67, Maka mereka kembali kepada kesadaran mereka dan berkata: "Sesungguhnya kamulah yang menzalimi (diri sendiri)". Kemudian mereka menundukkan kepala (lalu berkata): "Engkau (Ibrahim) pasti tahu bahwa (berhala-berhala) itu tidak dapat berbicara." Dia (Ibrahim) berkata: Mengapa kamu menyembah selain Allah, sesuatu yang tidak dapat memberi manfaat sedikitpun, dan

52 Ibid., 455. 
tidak (pula) mendatangkan mudarat kepada kamu?" Celakalah kamu dan apa yang kamu sembah selain Allah!. Tidakkah kamu mengerti?"53 Ayat ini menjelaskan bahwa mereka kembali kepada kesadaran rasionalnya, bahwa memang benar patung tidak layak dijadikan Tuhan, bahkan mereka menundukkan kepala, tanda rasa malu, tidak bisa berkata-kata apa-apa lagi untuk mendebat argumen Nabi Ibrahim. Bahkan mereka sendiri kemudian mengucapkan bahwa patung yang dijadikan Tuhan itu tidak dapat berbicara. Inilah yang kemudian menjadi argumen serangan (rebuttal) Ibrahim, dengan menyatakan kalau memang patung itu tidak mampu berbicara, lantas kenapa kamu sembah?, bahkan patung itu juga tidak mampu memberi manfaat atau keburukan kepada kalian. Lalu Nabi Ibrahim menyerang lagi dengan kalimat "celakalah kamu dan apa yang kamu sembah". Serta memberikan pertanyaan yang retorik untuk menggugah akal pikiran mereka, "tidakkah kamu mengerti?".

Dari ayat tersebut, dapat dipahami pola argumentasi Nabi Ibrahim ketika bermujadalah dengan masyarakatnya dalam QS. Al-Anbiya ayat 62-63, beliau menyampaikan pernyataan (claim) bahwa patung-patung tidak bisa disembah, hanya Allah saja yang harusnya disembah. Alasan atau ground yang digunakan adalah karena patung-patung itu tidak bisa berbicara, tidak dapat memberi manfaat atau mudarat sedikitpun kepada manusia. Dalam argumentasinya juga terdapat penjamin (warrant), bahwa seharusnya yang disembah adalah Tuhan yang Maha Pencipta, Yang Mahakuasa dan tidak mudah dihancurkan.

53 Ibid., 455-456
Keunikannya adalah alasan (ground) ini disampaikan dengan metode empiris yakni dengan memotong kepala patung-patung lalu membiarkan patung yang besar, kemudian menyuruh mereka untuk menanyai patung yang besar yang membawa kapak. Ground atau alasan ini juga secara tidak langsung menjadi serangan bagi argumen lawannya. Selanjutnya Nabi Ibrahim kemudian menyerang atau rebuttal mereka dengan argumen celakalah apa yang kamu sembah selain Allah. Serta memberikan pertanyaan yang retorik untuk menggugah akal pikiran mereka, "tidakkah kamu mengerti?". Di dalam rebuttal tersebut terdapat modal qualifier, bahwa jika mereka tetap menyembah patung tersebut akan celaka, sebaliknya jika berhenti menyembah patung dan mau menyembah Allah yang Maha Esa mereka akan selamat/tidak celaka.

Ketika tidak bisa menjawab argumen Nabi Ibrahim, umatnya kemudian memberikan serangan fisik yakni membakar Nabi Ibrahim. Dalam QS. Al-Anbiya' ayat 68-71 Allah berfirman yang artinya, "Mereka berkata: "Bakarlah dia dan bantulah Tuhantuhan kamu, jika kamu benar-benar hendak berbuat." Kami (Allah) berfirman: "Wahai api! jadilah kamu dingin, dan penyelamat bagi Ibrahim", mereka hendak berbuat jahat terhadap Ibrahim, maka Kami menjadikan mereka itu orang-orang yang paling rugi. Dan Kami selamatkan dia (Ibrahim) dan Luth ke sebuah negeri yang Kami berkahi untuk seluruh alam. ${ }^{\prime 54}$ Ketika masyarakat Nabi Ibrahim tidak mampu menjawab serangan argumentasi yang diajukannya, mereka membalasnya dengan

${ }^{54}$ Ibid., 456 
sanksi fisik. Hal ini menunjukkan bahwa argumen mujadalah Nabi Ibrahim tidak terbantahkan. Respons masyarakatnya jauh dari prinsip mujadalah, yakni dengan membalas argumen dengan kekerasan fisik. Kemudian Allah menolong Ibrahim dengan kekuasaannya.

Pola argumentasi Nabi Ibrahim ketika bermujadalah dengan masyarakatnya tidak di awali dengan mengajukan pernyataan (claim bahwa Tuhan yang seharusnya adalah Tuhan Pencipta langit dan bumi, patungpatung tidak layak disembah. Nabi Ibrahim memberikan ground atau alasan yang menunjukkan bahwa berhala tidak bisa menciptakan alam semesta, tidak bisa mendengar, melihat, bahkan dia diciptakan. Ground tersebut sebenarnya didukung oleh warrant, bahwa Tuhan seharusnya bisa berbicara, menciptakan alam semesta, bisa menolong dirinya sendiri, tidak mudah dihancurkan. selanjutnya Nabi Ibrahim menyerang atau rebuttal terhadap argumen masyarakatnya, serangan argumennya tidak terbantahkan oleh lawan debat.

Dalam debat kali ini, Nabi Ibrahim menggunakan Pola Argumentasi ke-5, yakni menggunakan semua elemen argumentasi mulai pernyataan (claim), dukungan bukti (ground), juga penjamin (warrant), juga ada bukti pendukung secara empiris yakni patung-patung yang telah dihancurkan dan ada yang masih utuh (backing), dikuatkan dengan modal qualifier, dan juga terdapat serangan-serangan yang tajam (rebuttal). Ini membuktikan pola argumentasi Nabi Ibrahim dalam mujadalah dengan umatnya termasuk kuat.

Selanjutnya, ada kekhasan dari mujadalah Nabi Ibrahim dengan masyarakatnya yakni menjadikan patung yang mereka sembah sebagai alat utama untuk menyerang argumentasinya. Hal ini membuat jatuhnya argumen lawan sangat telak. Ini bisa jadi karena Nabi Ibrahim melihat masyarakatnya yang awam, perlu diberikan dalil yang empiris untuk membuktikan bahwa patungpatung tersebut tidak layak disembah. Terbukti, bahwa hal itu membuat masyarakatnya tidak membantahnya. Akan tetapi karena tidak mau terbuka terhadap kebenaran, mereka tetap tidak mau menerima argumentasi Nabi Ibahim. Malah memberikan ancaman fisik terhadap Nabi Ibrahim.

\section{Pola Argumentasi Mujadalah Nabi Ibrahim dengan Raja Namrud}

Dalam QS. Al-Baqarah ayat 258, Nabi Ibrahim menjelaskan tentang Tuhannya (Allah). Dalam ayat tersebut terdapat pernyataan, "Apakah kamu tidak memperhatikan orang yang mendebat Ibrahim tentang Tuhannya (Allah) karena Allah telah memberikan kepada orang itu pemerintahan (kekuasaan)." Kalimat dalam ayat tersebut menunjukkan pernyataan (claim) yang dibangun oleh Nabi Ibrahim adalah tentang Tuhan, bahwa hanya Allah satu-satunya Tuhan yang harusnya disembah yang dalam kalimat tauhidnya $L \hat{a}$ ilâha illallâh. Pernyataan (claim) tentang kebenaran ajaran Tauhid yang diutarakan Nabi Ibrahim didasarkan pada bukti (ground) bahwa patung-patung yang disembah oleh Raja dan masyarakat saat itu adalah sesuatu yang tidak layak disembah, patung-patung itu adalah ciptaan manusia, tidak bisa menciptakan makhluk apalagi mengurusnya. Sehingga Nabi Ibrahim dari proses 
pencariannya secara rasional bisa membuktikan bahwa Tuhan yang benar bukanlah patung, melainkan Allah. Tuhan yang menciptakan bulan, matahari, bintangbintang, dan segala yang ada di alam semesta ini. Sehingga tujuan Nabi Ibrahim di sini jelas, yakni mengajukan pernyataan (claim) bahwa tidak ada Tuhan yang patut disembah selain Allah, yang secara tidak langsung berbeda bahkan bertentangan dengan keyakinan Raja Namrud.

Selanjutnya Nabi Ibrahim mengajukan ground (G) atau alasan yang menguatkan claim. Hal ini terdapat dalam kalimat, Ketika Ibrahim berkata: "Tuhanku ialah Yang menghidupkan dan mematikan." ${ }^{\prime 55}$ Kalimat ini didukung oleh penjamin (warrant) bahwa Tuhan seharusnya bisa menghidupkan dan mematikan makhluk.

Akan tetapi kalimat tersebut, disanggah (rebuttal) oleh lawan debatnya yakni Raja Namrud dengan mengatakan, "Saya dapat menghidupkan dan mematikan."56 Secara tidak langsung pernyataan ini menyerang balik dan bertujuan untuk mematahkan argumentasi Nabi Ibrahim. Kalau Tuhan yang diajukan oleh Nabi Ibrahim mempunyai karakteristik menghidupkan dan mematikan, Raja Namrud juga bisa membuktikan bahwa dirinya bisa menghidupkan dan mematikan manusia. Maksudnya dengan kekuasaan yang dimilikinya sebagai raja, tidak ada yang berani membantahnya, jika dia ingin membunuh manusia (dalam hal ini bawahannya) dia bisa, membiarkan bawahannya tetap hidup juga bisa. Dengan serangan tersebut secara tidak langsung, Raja Namrud ingin mengatakan bahwa kalau

55 Ibid., 53

56 Ibid., 53. karakteristik Tuhan adalah bisa menghidupkan dan mematikan, sedangkan Raja Namrud bisa melakukannya, maka Raja Namrud juga bisa menjadi Tuhan.

Menghadapi serangan argumen (rebuttal) yang cukup tajam dari Raja Namrud tersebut, Nabi Ibrahim kemudian menjawabnya dengan memberikan ground atau alasan kedua yang lebih kuat, yang langsung ditambahkan proposisi berupa serangan balik (rebuttal) terhadap argumentasi Raja Namrud. Dalam QS. AlBaqarah ayat 258, Nabi Ibrahim menjawabnya dengan kalimat "Ibrahim berkata: "Sesungguhnya Allah menerbitkan matahari dari timur". ${ }^{57}$ Alasan atau ground kedua yang dibangun oleh Nabi Ibrahim mempunyai landasan yang cukup kuat, bahwa Tuhan yang seharusnya selain bisa menghidupkan dan mematikan juga mempunyai karakteristik bisa menerbitkan matahari dari timur, karena Tuhan adalah sebagai penguasa alam semesta termasuk matahari, sebab Tuhan adalah Primum Mobile yang secara kebahasaan artinya adalah pencipta dan penggerak awal alam semesta. $^{58}$

Menerbitkan matahari merupakan pekerjaan yang tidak bisa dilakukan oleh siapapun manusia. Mungkin kalau menghidupkan dan mematikan manusia dengan kekuasaannya sebagai raja, Namrud bisa melakukannya, tapi bagaimana dengan menerbitkan matahari, apakah Namrud bisa? tentu saja tidak. Nabi Ibrahim ternyata tidak hanya menjawab dalam bentuk memberikan alasan atau ground saja, akan tetapi beliau juga langsung melakukan serangan argumen balik (rebuttal), yakni

57 lbid., 54.

58 Yusuf Suyono, Bertuhan Tanpa Agama?, 9. 
"maka terbitkanlah dia dari barat". Serangan atau rebuttal ini merupakan serangan yang canggih dan mematikan argumen lawan, sebab dilakukan dalam satu kalimat yang pendek bersama dengan ground atau alasan kedua, selanjutnya Nabi Ibrahim menyerang balik dengan menggunakan logika pembalikan, maksudnya Tuhannya Nabi Ibrahim bisa menerbitkan matahari dari timur, tentu kalau Raja Namrud yang sebelumnya secara tidak langsung mengaku dirinya Tuhan, seharusnya bisa menerbitkan matahari dari arah sebaliknya, yakni dari arah barat.

Karena kekuatan ground atau alasan kedua dan serangan balik (rebuttal) yang kuat inilah akhirnya Raja Namrud tidak bisa menjawabnya, dalam QS. Al-Baqarah:258 difirmankan oleh Allah, "Ialu bingunglah orang kafir itu; Allah tidak memberi petunjuk kepada orang-orang yang zalim. 159 Kebingungan orang kafir terutama Raja Namrud membuktikan bahwa dia tidak punya argumentasi lagi untuk membantah argumen serangan (rebuttal) Nabi Ibrahim. Sehingga dapat disimpulkan di sini, bahwa argumentasi Nabi Ibrahim mengajukan claim bahwa tidak ada Tuhan selain Allah, disertai alasan (ground), penjamin (warrant) dan disertai serangan (rebuttal) lebih unggul dan tidak terbantahkan. Dibandingkan dengan argumentasi Raja Namrud yang hanya melakukan satu kali rebuttal saja tanpa ada bangunan dukungan alasan yang kuat, dan tidak bisa menjawab serangan balik Nabi Ibrahim.

Pola argumentasi Nabi Ibrahim menggunakan pola ke-5 yakni menggunakan pola argumentasi yang terdiri dari pernyataan (claim), bukti atau alasan (ground), penjamin (warrant), lalu serangan (rebuttal). Jadi pola argumentasi ini berbeda dengan pola argumentasi ke- 5 Toulmin, yang harus ada backing dan modal qualifier. Nabi Ibrahim setelah membangun bangunan utama argumentasinya langsung melakukan serangan (rebuttal). Dan serangan pemikiran pertamanya berhasil dijawab dengan tajam oleh Raja Namrud, akan tetapi serangan (rebuttal) keduanya tidak dapat dijawab, merupakan serangan yang sangat telak. Pola argumentasi Nabi Ibrahim ini menggunakan pola berpikir rasional, bukan menggunakan metode empiris, sebab yang dihadapinya adalah Raja Namrud yang tentunya secara pemikiran bisa diajak berpikir rasional dan tingkat kecerdasannya tinggi. Hal ini juga dibuktikan dengan bantahan Raja Namrud yang cukup tajam membalikkan argumen awal Nabi Ibrahim. Akan tetapi Raja Namrud tidak mampu menjawab serangan Nabi Ibrahim yang kedua.

Seharusnya dengan kemampuan berpikirnya, Raja Namrud bisa berpikir jernih dan menerima pemikiran Nabi Ibrahim. Akan tetapi karena Raja Namrud dari awal tidak berusaha terbuka pemikiran, dia menolak kebenaran yang dibawa Nabi Ibrahim.

Permasalahan selanjutnya, ketika Raja Namrud tidak bisa membantah argumentasi Nabi Ibrahim, dia menggunakan cara-cara kekerasan, yakni membakar Nabi Ibrahim. Hal ini membuktikan bahwa Raja Namrud tidak siap untuk dialektika atau bermujadalah yang baik, sehingga ketika kalah dalam debat secara mental lalu menggunakan cara-cara kekerasan dengan mengerahkan kekuasaannya. Seharusnya

59 Departemen Agama RI, Al-Qur'an dan Terjemahannya, 54. 
bagi orang yang berakal, ketika argumentasi lawan debat tidak terbantahkan maka harus siap menerima kekalahan dan mengakui kebenarannya, minimal siap menerima perbedaan pendapat yang ada, siap jika banyak yang tidak mendukung pendapatnya, dan mendukung pendapat lawan debatnya, tidak malah kemudian menggunakan cara-cara kekerasan. Maha suci Allah yang kemudian menyelamatkan Nabi Ibrahim dari hukuman dibakar tersebut, dengan menjadikan api yang membakar Nabi Ibrahim menjadi dingin dan dapat menyelamatkan Nabi Ibrahim.

\section{Kesimpulan}

Kajian tentang pola argumentasi dalam mujadalah Nabi Ibrahim, baik mujadalah antara Nabi Ibrahim dengan ayahnya, Nabi Ibrahim dengan masyarakatnya, dan Nabi Ibrahim dengan Raja Namrud memiliki kekhasan pola argumentasi dalam mujadalahnya; Pertama, pernyataan (claim) yang dibangun senantiasa berkaitan dengan aspek tauhid, bahwa tidak ada Tuhan selain Allah. Menolak Tuhan-tuhan selain Allah yakni patung-patung. Kedua, dalam semua mujadalahnya, Nabi Ibrahim menggunakan pola argumentasi ke-5, artinya bangunan argumentasinya kuat juga disertai dengan pola serangan pemikiran (rebuttal) sangat telak, dan hampir sulit dibantah. Ketiga, ketika berhadapan dengan masyarakatnya yang awam, Nabi Ibrahim menggunakan pendekatan empiris untuk membangun argumentasinya, sedangkan ketika berhadapan dengan ayahnya dan Raja Namrud, Nabi Ibrahim menggunakan pendekatan rasional. Keempat, ada perbedaan dengan pola argumentasi Toulmin, sebab walaupun menggunakan pola argumentasi ke-5, Nabi Ibrahim dalam rebuttal disampaikan tidak selalu ada elemen backing ataupun modal qualifier. Kelima, ketika lawan debatnya tidak mampu menjawab argumen serangannya, mereka menggunakan serangan ancaman fisik berupa ancaman diusir seperti saat bermujadalah dengan ayahnya, juga ancaman disiksa dan dibakar saat bermujadalah dengan masyarakat dan Raja Namrud. Nabi Ibrahim menjawab serangan berupa ancaman fisik dengan bahasa yang baik bahkan dengan doa. Saat Nabi Ibrahim mendapat sanksi dari Raja Namrud dengan dibakar, ia mendapat pertolongan Allah sehingga tidak mati.

Dari kajian terhadap pola argumentasi mujadalah Nabi Ibrahim, maka implikasinya bagi komunikator dakwah, ketika hendak menggunakan metode dakwah mujadalah, perlu memperhatikan kekuatan argumentasi yang digunakan. Setiap pernyataan (claim) harus didukung oleh bukti-bukti yang kuat baik data (ground), penjamin (warrant), maupun pendukung bukti (backing) yang kuat. Selanjutnya dalam menyerang, fokus pada menyerang argumentasi lawan debat, serangan harus bisa mematahkan argumentasi lawan sampai tidak bisa menjawab. Selanjutnya dalam menyampaikan argumentasi harus menyesuaikan bahasa dan metode berpikir yang digunakan terhadap lawan debatnya. Terakhir, apabila dalam berdebat mendapatkan perlawanan berupa luapan emosi, kata-kata yang kasar, maka komunikator dakwah tetap membalasnya dengan bahasa yang baik. Untuk menghadapi ancaman berupa siksaan fisik, maka komunikator dakwah perlu memikirkan cara untuk mencari kemanan diri dan memohon pertolongan Allah. 


\section{Bibliografi}

Ash-shiddieqy, Hasbi. Ilmu-ilmu Al-Qur'an: Media-media Pokok dalam Menafsirkan Al-Qur'an. Jakarta: Bulan Bintang, 1992.

Departemen Agama RI. Al-Qur'an dan Terjemahannya. Surabaya: Penerbit Mekar, 2004.

Ennis, Robert H., Critical Thinking. New Jersey: Prentice Hall, Inc., 1996.

Fahri, Muhammad. "Metode Pengajaran Tauhid Nabi Ibrahim AS." Jurnal At-Ta'dib vol. 1, no. 3 (2015): 266-286.

Febriyanti, Beby Dwi. "Argumentasi Pada Teks Pidato Siswa Kelas X SMA Negeri I Rambipuji." ALASHR: Jurnal Pendidikan dan Pembelajaran Dasar, Prodi PGMI-FAI-Universitas Islam Jember vol. 2, no. 1 (2017): 1-22.

Gustira, Yinda Dwi. “Argumentasi Dalam Skripsi Mahasiswa S-1 Fakultas Kedokteran Universitas Lampung Tahun 2015 dan Implikasinya Dalam Pembelajaran Logika Pada PS-PBSI FKIP Universitas Lampung." Thesis Program Pascasarjana, Universitas Lampung, 2016.

Inch, Edward S., Barbara Warnick, and Danielle Endres. Critical Thinking and Communication: The Use of Reason in Argument. Boston: Pearson Education, Inc., 2006.

Kamdhi, J.S. Diskusi Yang Efektif. Cirebon: Kanisius, 1995.

Kamus Besar Bahasa Indonesia Online. Diakses 26 April 2020. https://kbbi.web.id,

Keraf, Gorys. Argumentasi dan Narasi. Jakarta: Gramedia Pustaka Utama, 1991.

Machendrawati, Nanih, dan Aep Kusnawan. Teknik Debat dalam Islam, dari Konsepsi sampai Aplikasi. Bandung: Pustaka Setia, 2003.

Moleong, Lexy J., Metodologi Penelitian Kualitatif, Edisi Revisi. Bandung: PT. Remaja Rosdakarya, 2015.

Qathan (al), Manna'. Mabahits fi 'ulumil qur'an. Riyadl: Mansyuratal-'Ashrial-Haditsah, tt.

Priyanto, Agung Teguh. "Penerapan Metode Dakwah Mujadalah Dalam Membendung Radikalisme Di Indonesia." Jurnal Inteleksia vol. 01, no. 02 (2020): 305-326.

Sabani, Noveliyati. "Generasi Milenial dan Absurditas Debat Kusir Virtual." Jurnal INFORMASI: Kajian Ilmu Komunikasi vol. 48, no. 1 (2018): 95-108. Doi: http://dx.doi.org/10.21831/informasi.v48i1. 18078.

Safitri, Dina. "Pola Argumentasi Kabinet Kerja dalam Membentuk Reputasi dan Branding di 2014." Conference: Konferensi Nasional Komunikasi Pariwisata dan Kewirausahaan FIKOM UNSAHID: Tata Kelola Komunikasi Kewirausahaan di Bogor (2015): 421-442.

Setianingsih, Yuliana. "Pola Argumen Paragraf Argumentatif Pada Artikel Jurnal Terakreditasi Bidang Ekonomi (Perspektif Stephen Toulmin)." Jurnal Adabiyat vol. 15, no. 2, (2016): 136156.

Shihab, M. Quraish. Tafsir Al-Mishbah, Pesan, Kesan dan Keserasian al-Qur'an, Cet. IV, Jilid. 6. Jakarta: Lentera Hati, 2011.

Siren, Nor Raudah, Badlihisham Nasir, Rohaily Rahman, and Ashraf Zedan. "Retorik al-Mujadalah Nabi Ibrahim dalam Al-Qur'an." International Journal of Quranic Research vol. 8, issue 1 (2016): 73-90.

Suyanta, Sri. "Kisah Ibrahim Mencari Tuhan dan Nilai-nilai Pendidikan." Jurnal Islam Futura vol. 6, no. 2 (2007): 100-118. DOI: http://dx.doi.org/10.22373/jiif.v6i2.3051.

Suyono, Yusuf. "Bertuhan Tanpa Agama?." Jurnal Teologia vol. 22, no. 2 (2011): 1-21. 
Tarigan, Henry Guntur. Berbicara Sebagai Suatu Keterampilan Berbahasa. Bandung: Aksara, 2008.

Toulmin, Stephen. The Uses Argumentation, Update Edition. New York: Cambridge University Press, 2003, 87.

Wuwur Hendrikus, Dori, Retorika Terampil Berpidato, Berdiskusi, Berargumentasi, Bernegoisasi, Yogyakarta: Kanisius, 2005.

Zaydan, Abd Karim. Usul al-Da'wah. Baghdad: Dar Umar al-Khattab, 1982. 
Tri Djoyo Budiono

26 | INTELEKSIA - Jurnal Pengembangan IImu Dakwah 